\title{
Implementation of Maqashid Sharia and Islamic Corporate Social Reponbility in Production Ethics
}

\author{
Mursyidi Abror \\ Faculty of Economics and Business Universitas Airlangga \\ mursyidiabror96@gmail.com
}

\begin{abstract}
Islamic economics is an economic system that is built on the basics and arrangements of the Qur'an and Al-Sunnah with the aim of maslahah. Production does not only create something that does not exist, but also makes goods resulting from several productive activities that have usability. A producer must contain Islamic values in their production activities. This value is reflected in the objectives in the production cycle must containgood luck and uphold the ethics and norms of both parties, namely consumers and producers whose ultimate goal is to achieve happiness in the world and the hereafter (falah). This article discusses ethical issues related to tempe producers and their relation to religion. The literaturereview used includes the concept of ethics, production theory, Islamic production ethics and production in Islam. At the end of the discussion, namely how a tempe producer creates a mashlahah in their production activities by implementing the maqashid sharia concept and the concept of social responsibility in Islam (ICSR) from the tempe production activities so that their activities achieve Islamic values: barokah, maslahah, falah, responsibility. social responsibility that synergizes with production theory.
\end{abstract}

Keywords: Production Ethics, Maqasih Syariah, Islamic CSR.

\begin{abstract}
Abstrak: Ekonomi Islam adalah sistem ekonomi yang dibangun di atas dasar-dasar dan pengaturan Al-Qur'an dan Al-Sunnah dengan tujuan maslahah. Produksi tidak hanya menciptakan sesuatu yang tidak ada, tetapi juga membuat barang dihasilkan dari beberapa kegiatan produktif yang memiliki kegunaan. Seorang produsen harus mengandung nilai-nilai Islam dalam kegiatan produksi mereka. Nilai ini tercermin dari tujuan dalam siklus produksi harus mengandung keberuntungan dan menjunjung tinggi etika dan norma kedua belah pihak, yaitu konsumen dan produsen yang tujuan utamanya adalah untuk mencapai kebahagiaan di dunia dan akhirat (falah). Artikel ini membahas isu-isu etika yang berkaitan dengan produsen tempe dan hubungannya dengan agama. Pandangan literatur yang digunakan mencakup konsep etika, teori produksi, etika produksi Islam dan produksi dalam Islam. Di akhir diskusi, yaitu bagaimana produsen tempe menciptakan mashlahah dalam kegiatan produksinya dengan menerapkan konsep maqashid syariah dan konsep tanggung jawab sosial dalam Islam (ICSR) dari kegiatan produksi tempe sehingga kegiatan mereka mencapai nilai-nilai Islam: barokah, maslahah, falah, tanggung jawab. tanggung jawab sosial yang bersinergi dengan teori produksi.
\end{abstract}

Kata kunci: Etika Produksi, Maqasih Syariah, CSR Islam. 


\section{INTRODUCTION}

Production is an activity carried out by humans in producing a product, both goods and services which are then used by consumers. When human needs are still few and simple, production and consumption activities are often carried out alone, namely someone produces to meet their own needs. However, along with the increasing diversity of needs and limited resources, a person can no longer produce the goods and services he needs himself, so he needs another party to produce whathe needs.

This production activity is also a chain of consumption, without a production activity that produces goods and services, there will be nothing that can be consumed and life activities will stop, causing economic activity to slow down. Humans need to eat, drink to be able to move, and need clothes to cover their genitals and worship, and need a place to live to protect themselves as well as various other needs.

Meanwhile, in Islamic production, it departs from human status as a'abd and caliph fi al-ard. With this status, production activities become a manifestation of human submission to Allah SWT. Production activities are not just an effort to meet the needs of life as agay economics but also a means to seek social justice and maintain the dignity of human beings and provide maslahah. So producers have the same goal in economic activity, namely achieving good luck the optimum.

In managing resources, the process of production activities must of course be based on Islamic values, which will later lead to the benefit of the people. Do not let production activities only based on the lust of greed in an effort to get the maximum profit with the smallest sacrifice which will bring harm to humans. Al-Qur'an and as- Sunnah become a frame of reference to return production activities to their original goal of increasing total human welfare (in terms of as-Syaibani called 'imaratul kaun). All production processes and activities lead to the glorification of human status, improvement of living welfare, eliminating socioeconomic inequalities, and having apositive impact on economic growth and independence as well as being able to provide welfare to the surrounding environment.

As an activity that produces goods and services, production emphasizes the relationship between input used and output resulting from. The position of producers is to meet the needs of the community. This goal has far-reaching implications. In addition to meeting the scale of needs based on consumer demand and increasing producer welfare, production activities also have a social function, namely distributing community welfare as a producer's social responsibility. In other words, increasing the welfare of producers is accompanied by the obligation to distribute their wealth in the form of zakat, alms, infaq or CSR funds corporate social responsibility). The objectives of meeting community needs and increasing producer welfare are carried out within the sharia corridor. 
Isla $\mathrm{m}$ actually accepts the production motive as the motive in the conventional economic system, only further that Islam also adds moral values in addition to economic utility. Humans are required to meet their needs and must be able to survive for their survival (Rianto, 2004). One way that can be taken by humans is by producing tempeh, which is a type of traditional food that is widely produced by Indonesian people. The tempeh home industry production itself does not operate in the (clothing) and board (residential) sectors only, but also in the food sector. The term home industry is a food sector where tempe production is a rapidly growing sector and has many choices for consumers. Therefore, the author wants to study further through this study entitled "implementation of maqashid sharia and islamic corporate social responbility in production ethics".

\section{LITERATURE REVIEW}

\section{Definition of Ethics}

Ethics comes from the word ethos. ethosin Greek has the meaning of morals or beliefs that guide a person or group. Ethics is defined as a systematic study of the nature of the concept of values, morals, good/bad, right, wrong and so on, and the general principles that justify us to implicate them in whatever we do. According to Isa Rafiq, ethics is a set of moral principles that distinguish good and bad. Ethics is a normative field of science because it plays a role in determining what an individual should or should not do (Muhammad, 2004).

The meaning of ethics in the Islamic economic paradigm will affect the mindset and community life in carrying out a production, ethics has a role, namely:

a. With ethics, a person or group can judge about human behavior

b. Ethics becomes a means of control or signs for a person or group to carry out an action or community activity

c. Ethics can provide prospects for overcoming the moral difficulties we face today

d. Ethics can be a fundamental principle for society in carrying out its activities

Ethical issues have been discussed a lot in the Qur'an and al-Hadith. Ethics is a moral system based on belief in God, and of course based on religion, with that the Qur'an and al-Hadith are the main sources that determine the boundaries in daily actions for humans, so ethics in production is part of human actions in carrying outthe corridors that have been determined in Islam.

The Qur'an has also explained about ethics that there are three basic keys that form the basis for ethics, namely faith, Islam and taqwa. If you think about it, it will have a very identical meaning. Faith means freedom from danger, peace and Islam means safe and integral, protected from disintegration and destruction, while taqwa is something that is fundamental to the Qur'an from these two terms and taqwa has the meaning of guarding 
against destruction, futility and disintegration. So that the discussion of ethics contained in the Qur'an contains a broad horizon because it involves the values contained in human life both individually, in society and in the state in general in order to achieve happiness both in the world and in the hereafter (Saiffudin, 2019).

So simply ethics is a set of moral principles that distinguish between good and bad. Ethics is very important to be applied in the production process to minimize wrong production activities that cause losses, so that the rules of values and norms have a very important position in controlling actions so as not to cause harm to other humans (Tamamudin, 2016).

\section{Production Theory}

Production theory is an activity to create and add usefulness (utilities) somethinggood or service. Factors of production in economics, such as land, labor, and skills (Assruri, 1986). The definition of production is not limited to the act of goods, but involves all activities that can add or create the use of an item, so activities that produce services include production (Tamamudin, 2016).

The theory of production is divided into two parts, namely the theory of short-run production and the theory of long-run production. The theory of short-term production is that if a producer uses factors of production, there are variable and fixed ones. The longterm production theory is that if all the inputs used are variable inputs and there are no fixed inputs, so it can be assumed that there are two types of production factors, namely labor (TK) and capital (M) (Aziz, 2003). In economics, this theory of production always raises a question about:

1. What will be produced and in what quantity

2. How to produce/produce these goods and or services.

3. For whom (for whom) the goods and or services are produced/produced.

In answering this, the company that will produce a product faces limited resources (factors of production), so the company chooses the best alternative that will be used to produce the desired product. Furthermore, the way the company produces the desired product is illustrated in the production process. Every production process has the main elements of the production system, namelyinput, process and outputt. Input are the resources used in the production process, the process is the method used to produce the product and the output is the desired product. Then this can be described by using the scheme (Soeratno, 2000): 
Figure 1. Production System Schematic

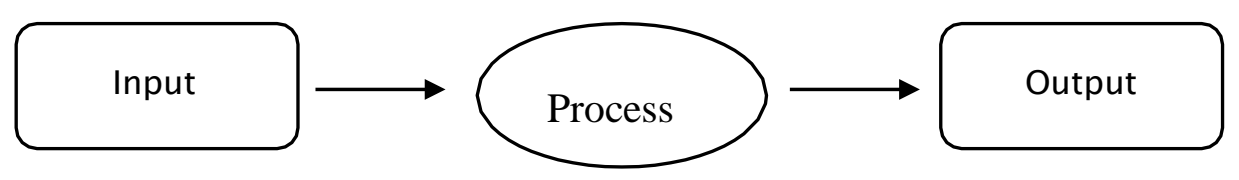

How? What?

Production is also an activity that converts inputs into outputs. Many types of activities that occur in the production process, such as changes in form, place and time of use of the products.Output company on the type of enterprise goods production depends on the number of inputs used in production. Production is also a job that creates or adds value and use of goods or services. In order for the production run to create results, several factors of production (inputs) are needed.

To produce output, the production factors which are inputs need to be processed together in a production process (production method). To produce a number of inputs are needed, namely the presence of capital, labor and technology. Thus there is a relationship between production and input in the form of maximum output produced with certain inputs or called the production function (Sugianto, 2002).

Production activities, both individuals and companies will always encounter three factors of production. Capital (K) or called input fixed, for example, such as land, machinery, buildings. Then Labor (L) are people who have skills or do not have skills and the last is Raw Materials (M) such as fuel (Perloff, 2012). Companies to combine these factors of production will take into account the production costs that can produce goods and services. Then the production function model appears to see the difference between output and input, namely $q=\mathrm{f}(\mathrm{L}, \mathrm{K})$. where $\mathrm{q}$ is the unit of goods and services produced using L (labor) and the amount of K (capital) issued. Then the company will consider the amount of labor and capital used to produceoutput in the context of efficiency even though profit maximization is not included in the production process, in other words in the amount of output certain companies will not want to use two workers if it can be done by one worker (Spell, 2020). The production activity in the economy is usually expressed in terms of the production function. The production function is a mathematical relationship that describes a way in which the amount of a given product depends on the number of certain inputs used.

\section{Islamic Production Ethics}

Ethics if associated with the production process must be oriented towards achieving harmony or balance for all or the various parties with an interest in production activities by understanding the good and bad of all actions taken. Ethics is also a reference (frames of reference) to produce goods and services, streamline performance and productivity, 
increase profits, and develop them widely. The urgency of ethics in production means glorifying humans as creatures of God, because humans are caliphs, and carry out social functions for society. This argument also refutes the existence of humans as merehomo economicus. In perspective homo economicus, ethics is separate from economics.

Whereas in Islam, production behavior is a manifestation of worship, morality, and human submission to God. Producers in Islam implement ethical values in the Qur'an and as- Sunnah in terms of meeting consumer demand, production processes, obtaining capital, business growth, and product diversification for business continuity. Because it cannot be separated from ethical values, production has a direct effect in social life (Fahrudin, 2010). This production process is the most important thing in the activities to create products, because if the production process is hampered then the circulation of economic activity will not be perfect, so Islam views that ethics is the most important part of the production process so that these production activities run smoothly. in doing business it is also production-oriented in Islam which includes (Djakfar, 2007):

\section{a. Oneness}

Related to the concept of monotheism, including the economic aspect is also regulated in it. This is the vertical dimension of Islam

b. Balance

Balance is shown to create the best rules, including balance in the economic field which is shown in awareness.

c. Free will

Islam teaches life without pressure in all things including in the economic sphere, humans have the ability to think and make decisions, to choose whatever way of life he wants, and most importantly, to act on what he chooses.

d. Responsible

Muslims are stressed to take into account everything that will be done. In the field of economics and business this principle is translated into a certain pattern of behavior. It has a multi-layered nature and focuses on both the micro (individual) and macro (organizational and social) levels, both of which must be carried out together.

e. Virtue

Ihsan or actions that benefit others without any particular obligation. Ihsan is the willingness of business people to give kindness to others, for example giving timeslack to the debtor and if necessary reducing the debt burden, accepting the return of goods that have been purchased and paying debts before the time of collection arrives.

These five ethical philosophies are oriented towards Islamic production activities due to the interconnectedness of the responsibilities possessed by a production actor accompanied by an ethical philosophy in attitude, namely oneness, balance, free will, responsibility, and virtue (Tamamudin, 2016). The production process to marketing and service to consumers all must follow Islamic ethics. Metwally said that the difference in 
production that uses Islamic ethical values with non-Islamic ethics lies not only in its objectives, but also in its economic policies and market strategies. There are several things that must also be considered in this production ethic (Faizal, 2016):

a. Types of products

Products to be produced must comply with sharia principles regarding goods and production. In Islam, the main principle in production is Halal toyyibah and beneficial as stated clearly in the verses of the Koran (al-Nahl, 16: 114). Halal toyyibah means that it can be consumed in relation to Islamic teachings as long as it is safe and not harmful. Muslims should avoid any food or drink that lies syubhah.

b. Maintaining Production in an Ethical Way

Muslim entrepreneurs must be able to produce products that are Halal toyibah continuously, thus that the Muslim entrepreneur is able to demonstrate his ability to comply with all the principles and rules of production in Islam. If the production of Halal toyyibah placed as a priority, it must be supported through the use of halal resources and legal work procedures. If Muslim entrepreneurs can avoid elements of haram elements such as fraud and usury continuously, then the application of IBE in production will be maintained. To maintain ethical production, entrepreneurs need to believe and be prepared to make small profits. Their willingness to accept these conditions will help them to remain ethical in producing their products.

\section{c. Relationship of Islamic Business Ethics with Halal Certification}

Halal certification is issued by the authority as confirmation that a product must meet the procedures and standards set in accordance with Islamic principles. Technically, verification and halal status will allow users to make choices about products on the market. From this explanation, we can conclude using the table:

Table 1. The Parameters of Islamic Business Ethics in Production

\begin{tabular}{|l|l|}
\hline \multicolumn{1}{|c|}{ Scopes } & \multicolumn{1}{c|}{ Parameters } \\
\hline Type of Products & $\begin{array}{l}\text { Halälan Toyyibā; beneficial; clean and pure; } \\
\text { fulfilling the Maslahah; no harm; comply with al- } \\
\text { Maqāsid al-Shari'ah, cleanliness, based on } \\
\text { priority (al-Awlawiyyat) value of worship (al- } \\
\text { 'Ibadah) }\end{array}$ \\
\hline Retaining the Production in Ethical Manner & $\begin{array}{l}\text { Haläl resources; legal work procedures, avoiding } \\
\text { the Harām elements }\end{array}$ \\
\hline Haläl Certificates & $\begin{array}{l}\text { Follow the Islamic ruling and the authorities } \\
\text { regulations }\end{array}$ \\
\hline
\end{tabular}

\section{Production in Islam}

Production activities in the perspective of Islamic economics are related to humans and their existence in economic activities, production is an activity to create wealth by utilizing natural resources by humans. Production is commonly defined as creating value 
for goods or adding value to a product, goods and services produced must only be permitted and profitable (halal and good) according to Islam (Haneef, 2010).

Production does not mean only physically creating something that does not exist,but what humans can do is make useful goods resulting from several production activities, because no one can create completely new objects. Making an item useful means producing an item that suits the needs of the community and has a high selling power (Fauzia and Riyadi, 2014):

Figure 2. The Concept of Production in Islam

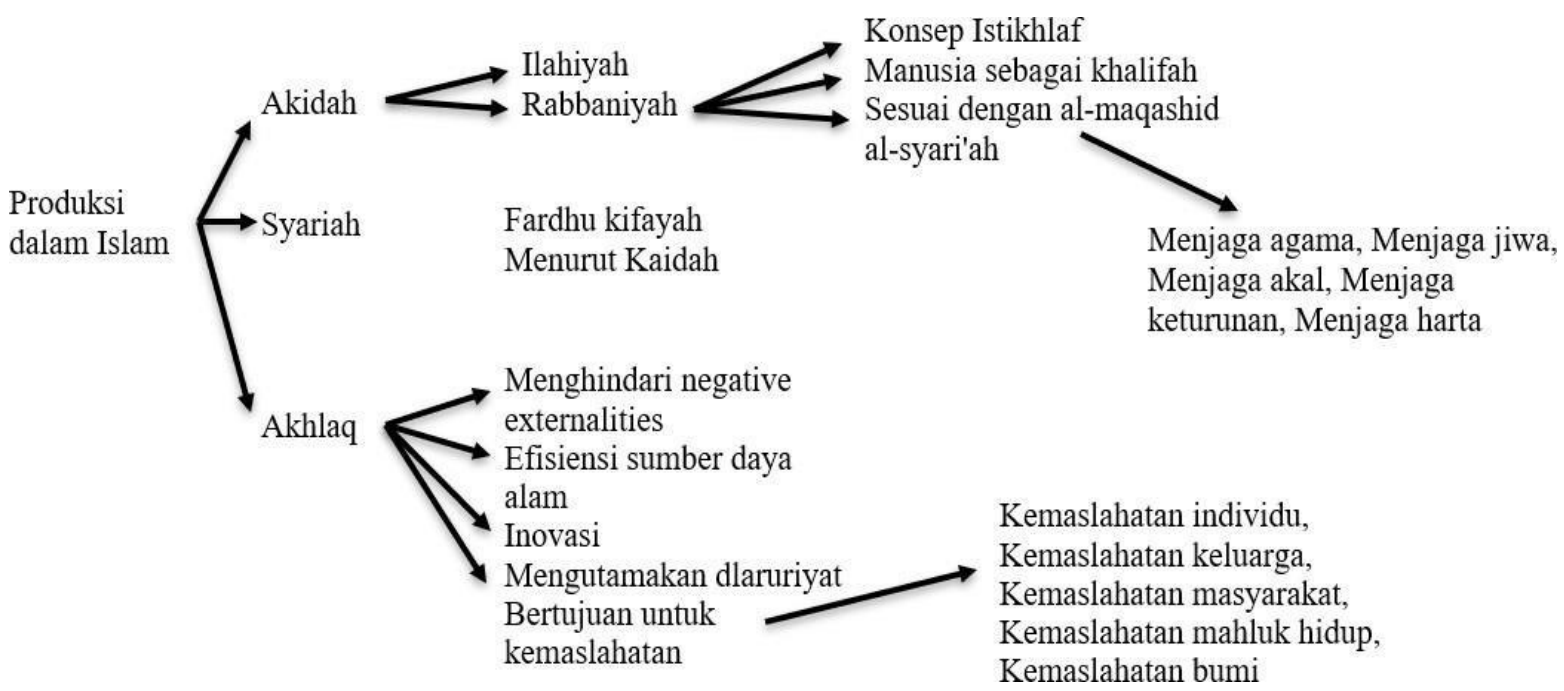

The production objectives in the perspective of the economic fiqh of the caliph Umar bin Khatab are as follows:

a. Realizing the maximum possible profit

Realizing profit as optimally as possible means that when producing is not just routine production or the origin of production but must really pay attention to the realization of profits, however, this goal is different from capitalist understanding which seeks to achieve as much profit as possible.

b. Realizing individual and family sufficiency

A Muslim is obliged to carry out activities that can realize his sufficiency and the adequacy of people who are his livelihood obligations.

c. Don't rely on other people

Umar ra as taught in Islam does not justify / allow someone who is able to work to raise his hand to others by begging and calling on Muslims to rely on themselves, not expecting what is in the hands of others.

d. Protect property and develop it

Wealth has a big role in Islam. Because with wealth, the world and religion can be upheld. Without wealth, a person may not be istiqamah in his religion and not calm in his life. In Umar's economic fiqh there are many narrations that explain the urgency of wealth, and that wealth is very much needed for the enforcement of various world 
and religious problems. Because, in the world of wealth is as glory and honor, as well as to protect one's religion more. In it there is goodness for someone, and connects the relationship with others. Therefore, Umar ra called on humans to maintain wealth and develop it by exploring it in production activities.

e. Explore economic resources and prepare them for use

The sustenance created by Allah swt. not only property that is in the hands of a person, but includes everything that is entrusted by Allah SWT. on this earth so that it can be used as a tool to meet their needs and pleasures. Allah SWT. has prepared for humans in this world many economic resources, but in general to be able to be utilized, exploration must be carried out in the form of production activities so that it can meet human needs.

f. Liberation from the shackles of economic dependence

Production is the most important means in realizing economic independence. A nation that produces its needs is a nation that is independent and free from shackles economic dependence on other nations. Meanwhile, a nation that only relies on consumption will always be a prisoner of the economic shackles of other nations.

g. Taqarrub to Allah SWT

A Muslim producer will get a reward from Allah SWT. This is due to its production activities, both for the purpose of gaining profit, realizing stability, protecting property and developing it or other purposes as long as he makes these activities as an aid in obeying Allah SWT (Hakim, 2012).

All production goals in Islam are basically to create maslahah that optimum for humans as a whole so that falah will be achieved which is the ultimate goal of economic activity as well as the goal of human life. Falāh itself is the glory of life in this world and the hereafter that will give true happiness to humans. Thus, production activities are very concerned about the glory and dignity of humans, namely by raising the quality and degree of human life. The dignity of human dignity must receive great and primary attention in all production activities, because all activities that are contrary to the honor of human dignity are contrary to the teachings of Islam (P3EI) UII). Therefore, production activities in the perspective of Islamic economics are related to humans and their existence in economic activities (Al-Arif, 2011).

In economic terms, production is a cycle of economic activities to produce certaingoods or services by utilizing production factors within a certain period of time (Marthon, 2004). There are several factors as a means of production, namely:

a. Natural/soil factors

Natural factors are basic factors in production. The nature referred to here is the earth, and all its contents, both on the surface of the earth, and those contained within the earth itself. In production, all of these are categorized as natural resources that can be utilized for the welfare and prosperity of mankind (Marthon, 2004). 
Rasulullah SAW. very concerned about the use of dead land (ihya al-mawat) as aresource for the prosperity of the people. Islam recognizes ownership of existing natural resources, by always striving for good use and maintenance of natural resources as a factor of production. It is intended to give encouragement to someone in developing (managing) the land. Islam also allows land owners to use other natural resources as production materials (Muhammad, 2004).

\section{b. Labor factor}

Labor is an efficient factor from the previous production factors, namely the natural. Manpower is also an asset for the success of a company, because the success of a production lies in the performance of the human resources in it. Workers who have good skills and integrity are the main capital for a company. Labor is the basis of productivity of all production factors that will not be able to produce any goods/services without the presence of labor (Fauzia and Riyadi, 2014). Thus, labor is needed to carry out the transformation process from materials to finished goods as desired by the company.

Labor is not only a number of businesses or services offered for sale to thecompany, so that those who employ workers have moral and social responsibilities, so that the basis for determining the amount of wages paid must be able to improve the welfare of the workforce concerned. without neglecting the level of work efficiency so as to reduce production costs (Gitosudarmo, 2002).

The right of work that must be fulfilled by the perpetrator is the fulfillment of the terms ofthe work contract that has been approved. One that must be fulfilled is the rights of workers. The rights that must be accepted by workers are (Djazuli and Janwari, 2002): get wages/salaries from their work, get job security from the employer, get health services and other social goals, get education so that the quality of work of the workers increases.

c. Capital factor (capital)

Capital is a very important factor in a production, therefore without capital producers cannot produce goods/services. Capital is the amount of purchasing power or that can create power that is used for a production process, without capital it cannot produce and build. In Islam, capital must be sourced from something that is free from usury sothat goodness can be achieved in production activities and the achievement of maslahah (Fauzia and Riyadi, 2014). Fauzia and Riyadi (2014) distinguishes capital based on the source of capital, namely (Fauzia and Riyadi, 2014):

1. Capital from nature

All contents of natural resources that have not been declared to be owned by a person or legal entity can be used as production capital.

2. Own capital 
IMKA Implementasi Manajemen \& Kewirausahaan - Oktober, Vol. 1, No. 2, 93-114, 2021

Anything that belongs to a person can be used as capital for his business as long as the property or item is not prohibited or declared haram.

3. Loan capital

Loans obtained from other people or institutions and used as capital can overcome the shortage of production capital with a note that the loan system used must not contain elements of usury or violate sharia rules, even the more advanced the economy, the more transactions will be carried out by credit. Getting money (purchasing power) that comes from loans is called loan capital.

\section{d. Management Factor}

Management is the science and art of managing the process of utilizing human resources and other resources effectively and efficiently to achieve a certain goal (Hasibuan, 2004). Based on the management functions in the form of planning, organizing, directing and supervising, management means the process of planning, organizing, directing and supervising the financial, human and information resources of a company to achieve its goals. Without good management, all production factors will not produce maximum profit because all these production factors require regulation through a good managerial process (Fauzia and Riyadi, 2014).

The managerial process requires expertise, namely managerial skills which consist of two aspects, namely:

1. Skills to organize

The skill to regulate is a skill where a manager must be able to make arrangements or create rules or concepts for the development and development of the company he leads.

2. Skills to lead

The skill to lead is the ability to move so that the plans that have been made can run and be controlled so that the goals stated in the plan can actually be realized.Leadership activities have five main elements, namely exploring concepts, conveying concepts, motivating, directing or ordering and supervising or controlling. 


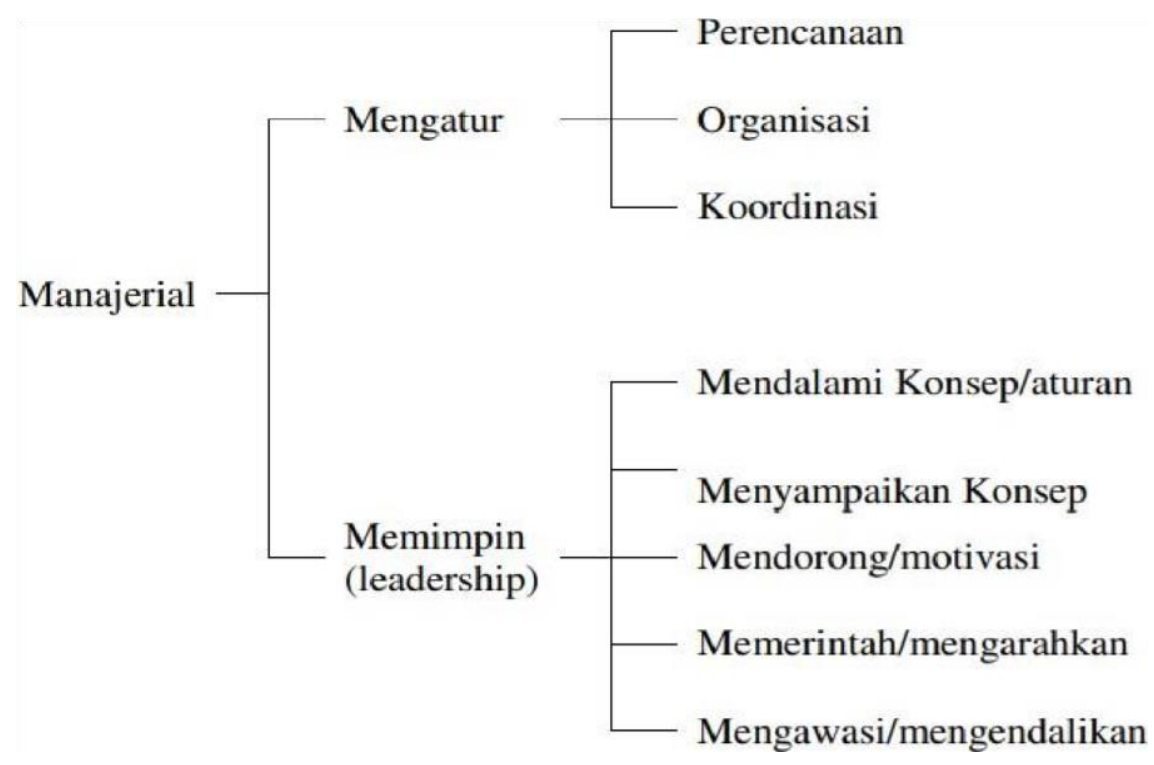

Figure 3. Managerial Skills Scheme (Gitosudarmo, 2002)

In carrying out the management function, the managerial will perform the following stages:

a. Planning Function

Planning is the determination of goals about the desired future state by selecting and determining the way to be taken from all possible alternatives to achieve these goals. The steps needed in planning are setting business goals andtargets, formulating strategies to achieve business goals and targets, determining the necessary resources and setting standards of success in achieving business goals and targets (Ernie Trisnawati Sule, 2008).

The planning carried out can function to set company goals and formulate them in a production program so that they can clearly distinguish the direction of each production activity, provide a formulation of the goals to be achieved, identify obstacles/risks that may arise in the company's operations and avoid uncontrolled growth.

The product planning process that will be produced cannot be separated from analyzing internal factors that can produce strengths and be able to find out their weaknesses. Companies also need to analyze external factors in the form of opportunities (opportunities) that are open and pressures (treatments) experienced by the organization/company. Analysis of internal and external factors is often known as SWOT analysis. 
IMKA Implementasi Manajemen \& Kewirausahaan - Oktober, Vol. 1, No. 2, 93-114, 2021

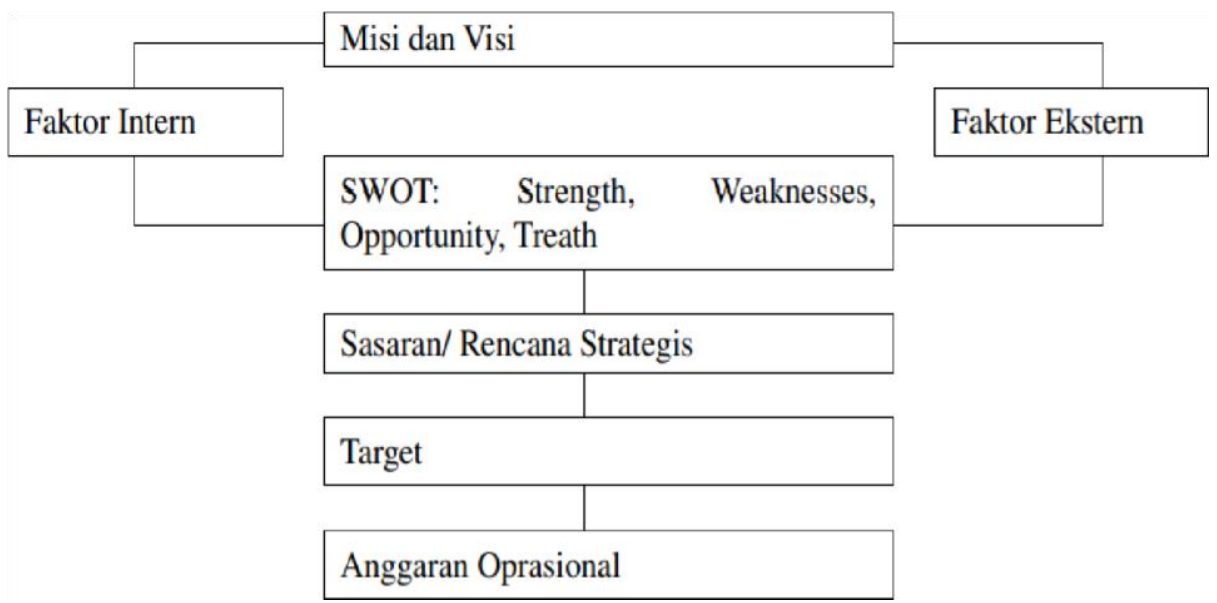

Figure 4. Planning Process Involving SWOT Analysis

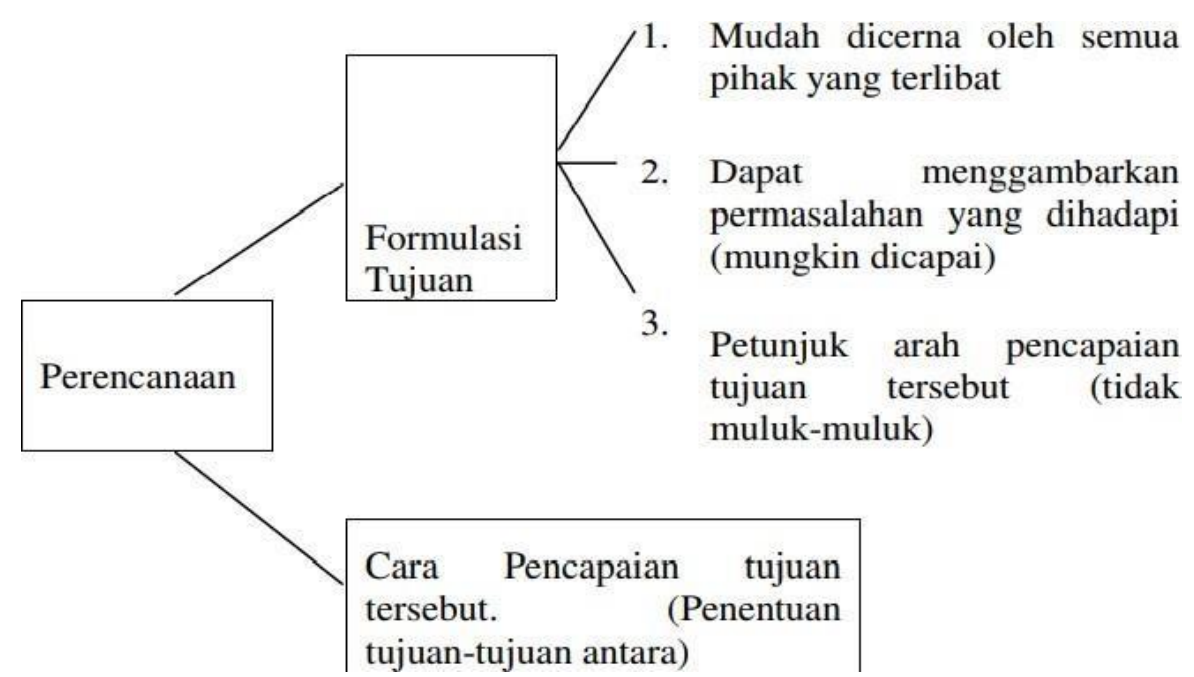

Figure 5: Planning Steps (GitoSudarmo, 2002)

b. Organizing Function

1. Allocating resources, formulating and assigning tasks and establishing the necessary procedures.

2. Establish an organizational structure that shows the lines of authority andresponsibility.

3. Carry out recruitment, selection, training and human resource development activities.

4. Placing human resources in the most appropriate position

c. Directing Function

1. Implement the process of leadership, mentoring and providing motivation to the workforce so that they can work effectively and efficiently in achieving goals.

2. Provide routine tasks and explanations regarding work and established policies. 


\section{d. Controlling Function}

1. Evaluate success in achieving goals and targets in accordance with predetermined indicators

2. Take steps to clarify and correct any deviations that may be found

3. Carry out various alternative solutions to various problems related to achievement (Sule, 2008).

e. Technology

In the current era of production progress, technology has a very large role in the production sector, because of this, many producers cannot survive because they cannot compete with other competitors who are able to produce goods/services better than what they produce. because it is supported by good technology equipment.

\section{f. Raw material}

A producer must first study the channels of raw material providers so that production activities run well (Sule, 2008) so that they do not hinder the production process. Production raw materials are sometimes something that can only be obtained or produced by nature without any substitute and there are also other materials that can be found to replace existing materials.

\section{RESEARCH METHODS}

This study uses a descriptive qualitative method, which is a study that uses qualitative data and then describes it descriptively. This type of research is used to analyze social conditions, events, or a phenomenon. The research focus in this article is how to analyze how to implement maqashid sharia and Islamic corporate social responsibility towards Islamic production ethics. In this study using primary data and secondary data. Primary data, namely data collection can be done by direct interviews, communication by telephone or indirect communication such as letters, emails and others. Secondary data is collecting data through indirect methods or having to do an indepth search first, such as through the internet, literature, statistics, books and others. Used in this study using the company's internal data that has been in advance (Prasanti, 2018).

The data analysis technique used in this study is qualitative data analysis, this analysis has 4 stages, namely collection, reduction, presentation and conclusion. Collecting data in this study using primary data, interviews with sources related to the company. Next is the data reduction stage, the data that has been obtained is analyzed, simplified, and discarded the part of the data that is not needed in order to produce relevant information. Then the data presentation stage, after the data is analyzed, the data set is arranged systematically. Presentation of qualitative data in the form of graphs, 
charts, networks, matrices or narrative texts. Through this stage, the data will be arranged ina pattern of relationships, and make it easier to draw conclusions. The final stage in this data analysis is drawing conclusions and verification. The data that has been collected, then researchers look for relationships, similarities, and differences and valid evidence in order to get answers to existing problems, so that they become a conclusion. The existence of data verification is intended so that the suitability of the data with the objectives in the analysis is more precise and rational (Rezkia, 2020).

This research method describes the analysis of data obtained from the results of research on the implementation of maqashid sharia and Islamic corporate social responsibility in production ethics. Because production is very much needed which has potential during a pandemic like today, so that optimal management can help the government and the community to deal with pandemic conditions like today. In conditions of uncertainty and difficulty like today, production is a concern during this pandemic (Kadir et al., 2020).

\section{DISCUSSION}

\section{Maqashid Sharia In Tempe Production}

Term of maqashid Derived from the Arabic language which means the principle, intent, purpose, intent, or purpose. When combined with the termshari'ah then it has a meaning as the intent and purpose of Islamic law or just the purpose of Islamic law. Maqashid shari'ah indicators are developed to achieve individual and public interests. This will be the basis for designing regulations in an Islamic economic system that understands values, measures and standards. This must be maintained in daily activities in halal business and trade (Kurnia, 2017).

In Islamic Economics, the purpose of production activity is to provide good luck for humans, where good luck This is the main basis for humans to fulfill needs, and these basics must be maintained, including: hifdzu ad-dien, hifdzu an-nafs, hifdzu al-'aql, hifdzu an-nasl, hifdzu al-maal. The explanation of the five basic human needs is as follows (Rafsanjani, 2016):

\section{a. Hifdzu Ad-Dien}

Maintaining or maintaining religion is maintaining religion (pillars of faith and pillars of Islam). Islam teaches humans to live their lives properly, as has been arranged by Allah SWT. In fact, it is the effort to live rightly and live life rightly that makes one's life of great value. The measure of the good and bad of a person's life is not measured by other indicators but by the extent to which a human being clings to the truth. For this reason, humans need a guide about the truth in life, namely religion.dien) (Herianingrum, 2014). 
Implementation hifdzu ad-dien In the production of tempeh in Kamal, Mr. Munir always pays attention to the raw materials that have been produced according to Islamic recommendations, namely that there are no elements of raw materials that are prohibited in the Qur'an and Hadith, for example choosing raw materials of good quality and avoiding raw materials. rotten stuff. Meanwhile, in running the organization, you can use Islamic concepts such as buying and selling that does not contain an element of disappointment (mutual pleasure). In addition, Islam also orders to issue zakat, infaq, and shadaqah. So the company realizes this and is distributed to the authorities in managing zakat, infaq and shadaqah such as mosques, LAZ or BAZ. These efforts were made to fulfill the five pillars of Islam that have been taught in Islam.

\section{b. Hifdzu An-Nafs}

Nurturing the soul is meant here, namely maintaining the physical so that it remains healthy and can still be active. body and soul life (an-Nafs) in this world is very important, because it is a field for crops to be harvested in the afterlife. What will be obtained in the hereafter depends on what has been done in this world. Life is highly respected by the teachings of Islam, because it is a gift given by Allah to his servants to be used as well as possible. Everything that can help the existence of life is automatically a necessity, and on the other hand, everything that threatens life (cause death) should basically be avoided.

Implementation hifdzu an-nafs in production activities in the tempe kamal homeindustry, namely producing healthy goods/products, such as raw materials used not using hazardous chemicals and not using formalin which can damage humanhealth.

\section{c. Hifdzu Al-'Aql}

Maintaining the mind is to keep the mind from being damaged, both physically and non- physically, physically means that the mind is not damaged by anything that is physically damaging, whether it is damaged by drugs or other things, while nonphysically means that the mind is not brainwashed with things negative things (Herianingrum, 2014).

Implementation hifdzu al-'aql in production activities in the tempe home industry,namely by not producing goods/products that can threaten brain damage such as formalin, a mixture of other raw materials (which can damage the tempe itself) or illegal drugs. In addition, it also provides training for employees in order to develop their insights and ideas in order to be able to create good quality and be able to compete at a higher scale such as the level of international trade.

\section{d. Hifzu An-Nasl}

To maintain the continuity of life, humans must take care of their descendants and families.nasl). Although a believer believes that the time horizon of life includes not only the life of this world but to the hereafter, the continuity of the life of this world is very important. Humans will maintain the balance of life in this world and in the hereafter. 
Therefore, the continuity of heredity and sustainability from generation to generation must be considered. This is a very important need for human existence.

The implementation of Hifdzu an-Nasl in production activities at the tempe kamal home industry, namely in the management of raw materials must be used as well as possible, not over-exploiting, especially during the pandemic season it is very difficult to find the raw materials, therefore the community can enjoy tempeh continuously.

\section{e. Hifdzu Al-Maal}

Maintaining property is maintaining property so that the property is not damaged / still exists and even develops. Material property (sorry) needed, both for worldly life and worship. Humans need property to meet the needs of food, drink, clothing, houses, vehicles, jewelr $y$ and various other needs to maintain their survival.

Implementation hifdzu al-maal in production activities, namely by always turningthe money earned to continue to be invested and developed. Don't let the money the profits from their production activities are stored/hoarded, because hoarding money will damage the wheels of the economy. Therefore, Islam prohibits the production and sale of dangerous goods except under certain conditions and under very strict conditions.

Based on the concept of maqashid shari'ah above, the model of economic development based on maqashid shari'ah production can be described using a scheme. The development process aims to achieve better worldly and hereafter welfare that is able to maintain social welfare in producing:

Figure 3. Maqashid al Sharia as a Model of Economic Development

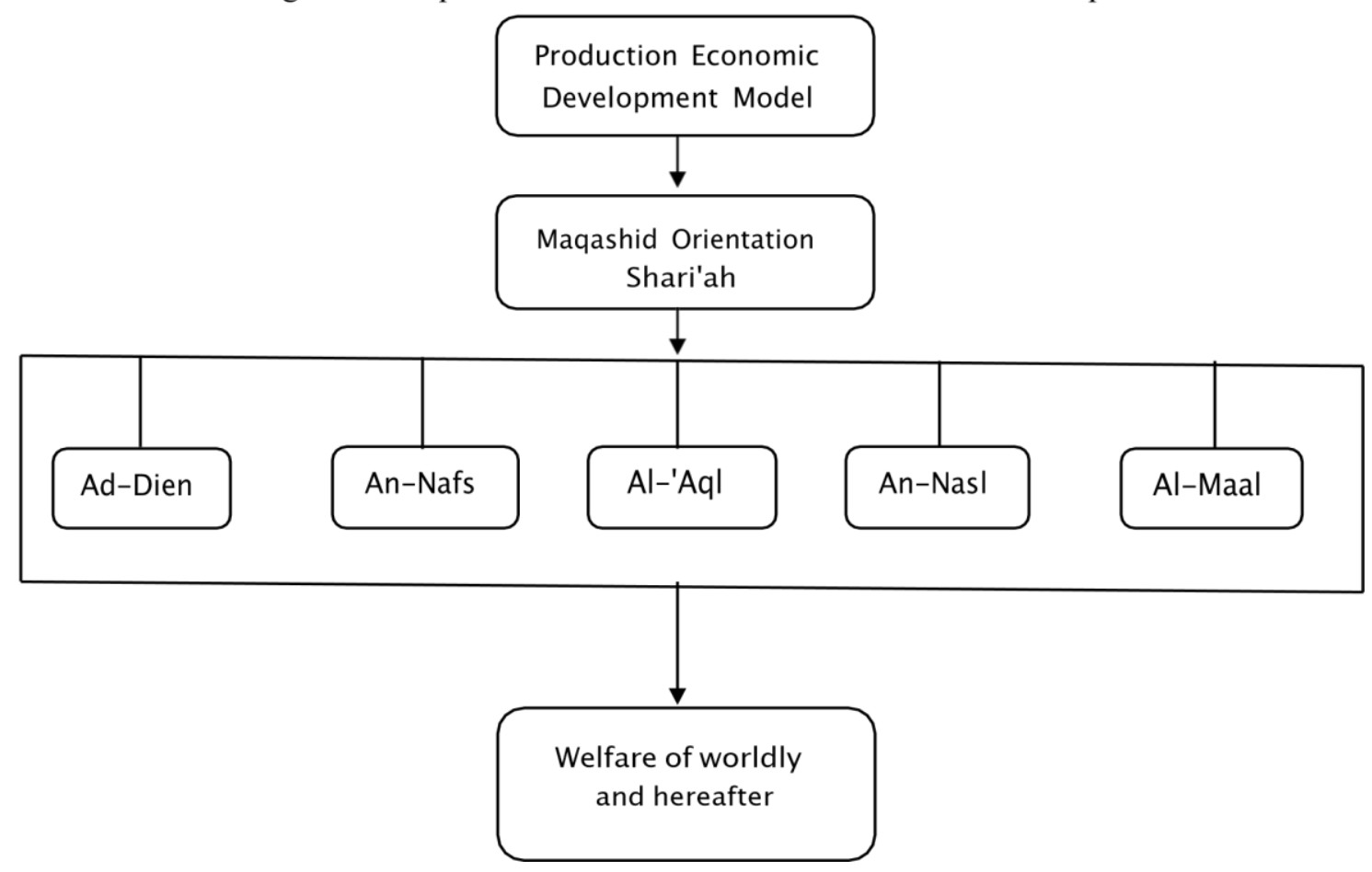


Production welfare is measured by using the maqashid shari'ah indicator, namely the maintenance of religion (ad-din), soul (an-nafs), sense (al-aql), descendants (an-nasl) and wealth (almaal) (Herianingrum, 2014), the production of tempe which is contrary to the maqashid sharia, such as drugs, tempe mixed with formalin or tempeh mixed with other raw materials that change the image of tempe itself (such as tempe mixed with grain and others) is still prohibited by Allah although these products are in high demand. Meanwhile, Suhaidi explained that cleanliness is very important in business and has a significant relationship with the concept of Halal toyiban. Muslims should not carelessly practice what is prescribed in the theory of production. On the contrary, they must ensure that every product produced must comply with the principles of Islamic teachings Islam has determined that every production activity should be based on priorities (alawlawiyyat) and according to maqashid shari'ah. Principle of al-awlawiyyat specifies that a product should be based on three priority levels. It starts withdaruriyyat goods (needs), followed by hajiyyat (needs) and finally tahsiniyyat (perfection). So, Islam has determined thatdaruriyyat goods must be prioritized in the production process.

Faizal also stated that following the principles of al-awlawiyyat and maqashid shari'ah in production is important in Islamic teachings. Therefore, must prioritize more production daruriyyat product, not hajiyyat and tahsiniyyat product. For example, if there is a Muslim who starts production or does business with a sense of responsibility towards other Muslims, then the Muslim entrepreneur must start his business by incorporating the values of halalan toyyibat and useful. Because Islam teaches that every product must have the value of worship. Islam stipulates that every product must allow its users to benefit (Faizal, 2016). The philosophical goal is more directed at the vertical type relationships found in the representation of wordsal-falah. Al-falahhas become the general goal of Islamic economics. It covers the area of human activity for the sake of Allah and is also achieved through the fulfillment of operational-based goals. Therefore, this goal requires a real assessment process to ensure its effectiveness and achievement in production activities (Omar, 2013).

\section{Islamic Corporate Social Responsibility in Tempe Production}

Corporate Social Responsibility (CSR) is the commitment of producers to contribute to developing a sustainable economy (sustainable economy) by paying attention to corporate social responsibility and focusing on the balance of life in the social, economic, and environmental fields (Budi, 2008). In other words, the CSR implemented in the tempe home industry is a symbiotic strategy between the company and the community in seeking mutual prosperity through dedication and the company's social role so as to create mutually beneficial harmonization. Various social and environmental problems that accompany economic developments have forced producers to redesign their production concepts so that they run synergistically with the conditions of society. On that basis, community involvement in implementing CSR programs in the tempe 
IMKA Implementasi Manajemen \& Kewirausahaan - Oktober, Vol. 1, No. 2, 93-114, 2021

home industry is very much needed. This can be done by inviting them to becomevolunteers, as an object of empowerment, and a source of information so that the CSR program is able to accommodate the aspirations and interests of the community concerned.

In the implementation of tempe production, producers are required to develop programs for CSR on an ongoing basis. This program is carried out in various activities that are prioritizedfor community needs and stakeholders. CSR programs can be referred to as producers' obligations because they must care and be involved in improving the welfare of the surrounding community. One of them is zakat, alms, and infaq. The producer's obligation to pay for this instrument is an early form of CSR program (Usman, 2016).

In addition, tempe production always practices CSR in that the company's operations must be free from various modes of corrupt practices and guarantee maximum service throughout its operations, including trusted services for each of its products. provision and development of safe and reliable products). In addition, Islam also provides signs and norms that can and should not be done in business. Islam allows its adherents to earn profits through the mechanism of trade (ba'i) and prohibits usury, maisir, gharar and gambling. This trading practice has also been exemplified by the Prophet Muhammad SAW and his companions in which an example of how to build Islamic business ethics is illustrated. Islam does not teach the practice of profit-taking which is accompanied by the emergence of adverse effects, oppressing and causing damage. So, in terms of regulation (shari'ah law), Islam clearly distinguishes between what is haram and what is lawful, both in terms of consumption, distribution, and production. All of these aspects in Islam must be passed in ways that are justified and do not violate Islamic Shari'ah rules (Muhammad , 2014). This is explicitly stated in the Qur'an (Surat al-A'raf verse 85). Allah SWT says:

"So complete the measure and the scales and do not reduce for humanstheir measures and scales,"

With this, then the practice of CSR if the intention is sincere to help people in need, itcan certainly be categorized into ghairu mahdhoh. That is, even though the program was originally not included in worship, but because it is solely to help others and hope for the pleasure of Allah SWT, the subject of the perpetrator will get a reward as well as doing worship.

This means that if the intention is planned like that, then the benefits of doing CSR are not only the company will be closer to the community. But what is more meaningful, the managers will be closer and get a reward from Allah SWT. If the CSR program is only economically motivated, then surely it will not get the reward of worship, because since Initially, the theological values have been realized which can actually be set since planning theprogram. That's why it's a loss for companies that carry out CSR programs only to achieve temporary worldly profits, completely separated from the transcendent 
theological values of ukhrowiyah. In Islam, there are general principles that companies must adhere to to help maintain economic balance, safeguard human rights, and ensure justice. These principles are in line with the four principles of Islamic business ethics, namely benevolence, relationships with others, equity, and accountability (Maurice, 2020).

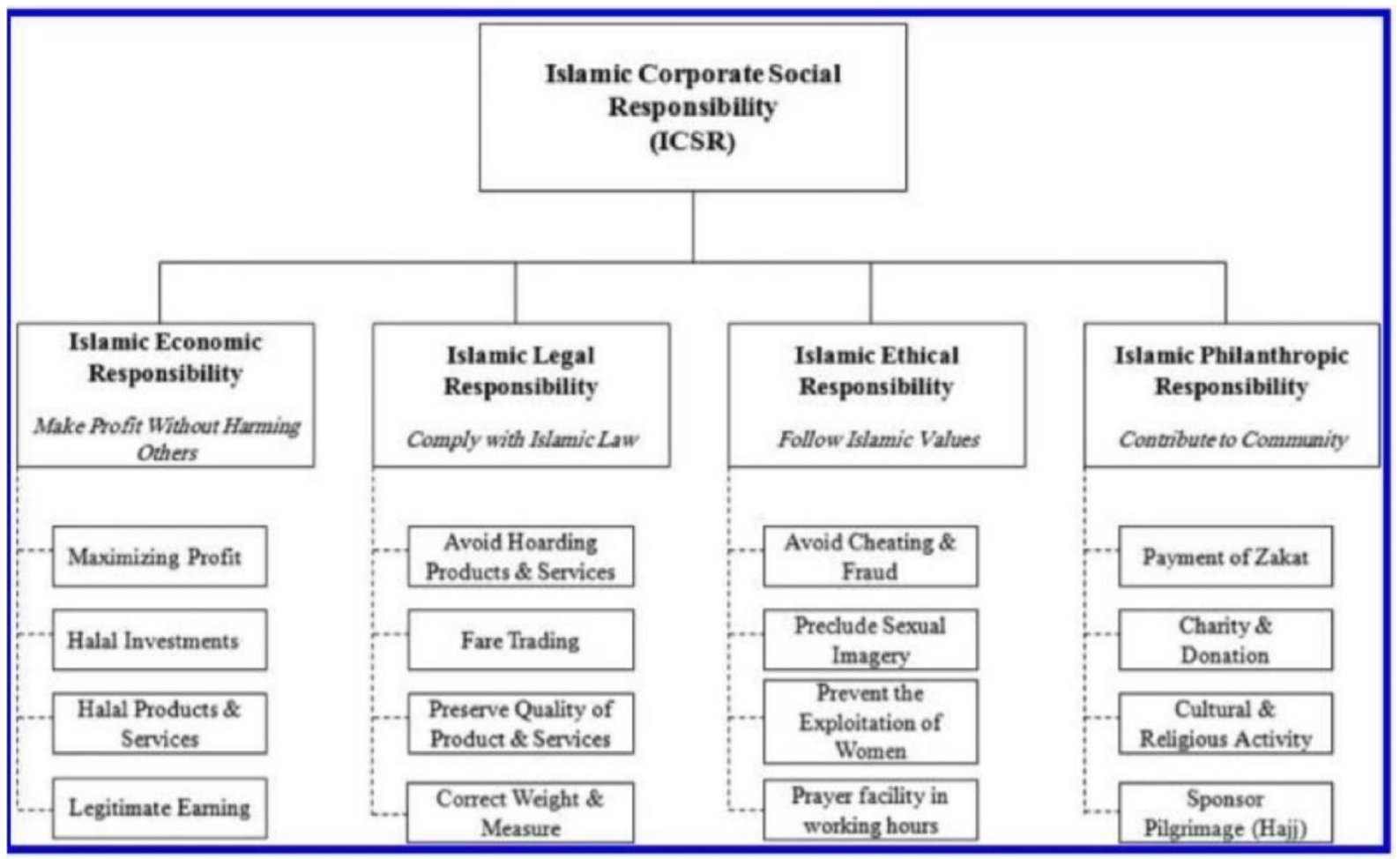

Figure 4. Islamic Corporate Social Responsibility Model

\section{CONCLUSION}

The tempe production process is an activity carried out by producers (Mr. Munir) to produce goods to meet the needs of life, with different motives, such as economic motives, which are profitoriented.profit), social-humanitarian motives, namely production activities are carried out because of positive benefits and do not cause moral (ethical) damage to the community and political motives, namely production activities are carried out in connection with the state's need for a production item as a supporter of government resilience and stability. In addition, the production process also pays attention to the values of justice and virtue (maslahah). Production is also a human effort to improve not only the physical condition of the material, but also morality as a means to achieve success fallah.

In carrying out tempe production activities, the company always tries to implement the principle of balance in all aspects. Because balance is the key to the survival of the company. Without maintaining a balance, the company will experience problems in the social environment which can have an impact on financial problems, the condition of these financial problems is not only bad for the company, but also for all parties related 
IMKA Implementasi Manajemen \& Kewirausahaan - Oktober, Vol. 1, No. 2, 93-114, 2021

to the company such as workers and their families, the surrounding community and suppliers. In addition, the purpose of tempe production activities must providegood luck for humans, wheregood luck There are five basic needs for humans that must be maintained, including: hifdzu addien, hifdzu an-nafs, hifdzu al-'aql, hifdzu an-nasl, hifdzu al-maal.

\section{DAFTAR PUSTAKA}

Al-Arif, M., \& Rianto, N. (2011). Dasar-dasar Ekonomi Islam. Solo: PT Era Adicitra Intermedia.

Assruri, S. (1986). Manajemen Produksi. Jakarta: Penerbit FE-UI.

Aziz. (2003). Pengantar Mikro Ekonomi, Aplikasi dan Manajemen. Malang: Banyumedia Publishing.

Budi, H. (2008). Corporate Social Responbility. Jakarta: Sinar Grafika.

Djakfar, M. (2007). Etika Bisnis Dalam Perspektif Islam. Malang: UIN Malang Press.

Djazuli, A., \& Janwari, Y. (2002). Lembaga-lembaga perekonomian umat (Sebuah Pengenalan). Jakarta: PT.Raja Grafindo Persada

Eja, A. (2020). Etika Produksi Islami: Maslahah dan Maksimalisasi Keuntungan. Ekonomi Islam, 2(1), 1-16.

Fahrudin, S. (2010). Etika Produksi Perspektif Ekonomi Islam. Ekonomi Islam al-Infaq, $1-9$.

Faizal, M. (2016). Parameters of Islamic Business Ethics in Productions. Global Business and Social Entrepreneurship, 11(2), 105-125.

Fauzia, I. Y., dan Riyadi, A. K. (2014). Prinsip Dasar Ekonomi Islam: Perspektif Maqashid al-Syari'ah. Jakarta: Prenadamedia Group.

Gitosudarmo, H. I. (2002). Manajemen Operasi, Edisi Kedua, Yogyakarta: BPFE Yogyakarta.

Hakim, L. (2012). Prinsip-Prinsip Ekonomi Islam. Jakarta: Erlangga.

Haneef, M. A. (2010). Pemikiran Ekonomi Islam Kontemporer. terj. Suherman Rosyidi. Jakarta: Rajawali

Herianingrum, S. (2014). Implementation of Maqashid al Sharia as a Model of Economic Development Agriculture in East Java. Business and Economics, 9(4), 23-40.

Kadir, A., Hakim, M. R., Syam, F., \& Karim, M. S. (2020). Penggunaan Dana Zakat Pada Korban Covid Perspektif Maqashid Syariah. Al-Tafaqquh: Islamic Law, 4(3), 5969.

Kurnia, F. (2017). Maqasid al-Shari'ah Based Performance Measurement for Halal Industry. Humanomics, 4(2), 1-25. 
Marthon, S. S. (2004). Ekonomi Islam di Tengah Krisis Ekonomi Global. Jakarta: BPFEYogyakarta

Maurice. (2020). Religion and CSR: An Islamic "Political" Model of Corporate Governance. Business and Society, 1-32.

Muhammad, A. (2014). Developing an Islamic Corporate Social Responbility Model (ICSR). Competitiveness Review, 8(2), 58-69.

Muhammad. (2004). Etika Bisnis. Yogyakarta: UPP AMP YKPN.

Omar, M. (2013). The Objective of Islamic Economic and Islamic Banking in Light of Maqasid Al- Shariah: A Critical Review. Scientific Research, 5(2), 32-48.

Perloff, J. (2012). Microeconomics. Boston: Addison-Wesley.

Prasanti, D. (2018). Penggunaan Media Komunikasi Informasi Kesehatan. LONTAR: Ilmu Komunikasi, 3(1), 26-42.

Rafsanjani, H. (2016). Etika Produksi Dalam Kerangka Maqasid Syariah. Perbankan Syariah.

Rezkia, S. M. (2020). Langkah-Langkah Menggunakan Teknik Data Kualitatif. Diambil kembali dari https://www.dqlab.id/data-analisispahami-teknik-pengumpulan-data

Rianto, A. (2004). Metodologi Penelitian Sosial dan Hukum. Jakarta: Granit.

Soeratno. (2000). Ekonomi Mikro Pengantar. Yogyakarta: STIE YKPN.

Sugianto. (2002). Ekonomi Mikro Sebuah Kajian Komprehensif. Jakarta: PT Gramedia Pustaka Utama.

Sule, E. T. (2008). Pengantar Manajemen. Jakarta: Kencana.

Tamamudin. (2016). Prilaku Produksi Industri Batik Kota Pekalongan Menurut Etika Produksi Islam. Jurnal Hukum Islam, 14(2), 1-23.

Usman, R. (2016). Islamic Perspective of Corporate. Islamic Perspective Corporate.

Muhammad, Z. H. (2004). Ekonomi Mikro Dalam Perspektif Islam. Yogyakarta: BPFEYogyakarta.

https://www.kompasiana.com/saiffudinachmad/5d2e8d72097f362ecc473494/etikaproduksidalamisam?page=all\#: :text=Pengusaha\%20muslim $\% 20$ harus $\% 20 \mathrm{mem}$ perhatikan\%20kemasla

hatan,produksi\%2C\%20karena\%20keharaman\%20babi\%20tersebut. 